\title{
Phenomenalism, or neutral monism, in Mach's analysis of sensations?
}

Book or Report Section

Accepted Version

Preston, J. (2021) Phenomenalism, or neutral monism, in Mach's analysis of sensations? In: Preston, J. (ed.) Interpreting Ernst Mach: Critical Essays. Interpreting. Cambridge University Press, Cambridge, UK. ISBN 9781108474016 Available at https://centaur.reading.ac.uk/90946/

It is advisable to refer to the publisher's version if you intend to cite from the work. See Guidance on citing.

Publisher: Cambridge University Press

All outputs in CentAUR are protected by Intellectual Property Rights law, including copyright law. Copyright and IPR is retained by the creators or other copyright holders. Terms and conditions for use of this material are defined in the End User Agreement.

\section{www.reading.ac.uk/centaur}

\section{CentAUR}

Central Archive at the University of Reading 
Reading's research outputs online 
Phenomenalism, or Neutral Monism, in Mach's Analysis of Sensations? ${ }^{1}$ John Preston

Introduction: Two Ways of Reading Mach

The more epistemological works of Ernst Mach, notably his great books The Analysis of Sensations (1886) and Knowledge and Error (1905), have often been interpreted as presenting some version of, or view related to, idealism, such as phenomenalism. Philosophers from diverse traditions, some close to Mach, others very negative about his work, have attributed to him views of this kind. Such readings of Mach unite allies of his such as Richard Avenarius, Hans Kleinpeter, the Logical Positivists (e.g., Rudolf Carnap and Philipp Frank) and their descendants (e.g. Rudolf Haller), with the harshest of his critics, such as V. I. Lenin, Edmund Husserl, Karl Popper, Gerald Holton, and John Blackmore. ${ }^{2}$

There has long been another way of understanding Mach's epistemological works, though. Bertrand Russell, for example, counted Mach a 'neutral monist', by which term he meant the view that 'the things commonly regarded as mental and the things commonly regarded as physical do not differ in respect of any intrinsic property possessed by the one set and not by the other, but differ only in respect of arrangement and context' (Russell 1914/1956, p. 139).

The latest and best exponent of the neutral monist reading was Erik Banks, whose work did more than anyone's to establish that Mach saw himself as, and should be thought of as, a neutral monist and not a phenomenalist (Banks 2003, 2014). I think Banks was right that something like neutral monism is Mach's best-considered position (or the best formulation of his position). However, that still leaves those who read Mach this way with a problem: how to explain why so many intelligent and thoughtful readers, some of them sympathetic to Mach, have thought of him instead as a phenomenalist. I

\footnotetext{
${ }^{1}$ For helpful comments on an earlier version of this chapter, I am very grateful to Pietro Gori and Luca Guzzardi.

${ }^{2}$ A very small sample of the many others who identify Mach as a phenomenalist, either in passing or at length, includes Robert Cohen (Cohen 1968/1970), Joseph Agassi (Agassi 1978/1988), and Klaus Hentschel (Hentschel 1985). Blackmore and his co-editors even subtitled one of their books on Mach 'Phenomenalism as Philosophy of Science' (Blackmore, Itagaki \& Tanaka 2001).
} 
propose to set out the factors which tempt people into reading Mach thus, and then assess the strengths and weaknesses of these two readings.

In this article I consider The Analysis of Sensations only, treating that as a relatively self-contained text. ${ }^{3}$ Recent scholars making the case for a neutral monist reading tend to do so by referring, entirely legitimately, to unpublished sources as well as to Mach's entire published oeuvre. What I hope to do here is to present an 'internal' view, showing that the text of The Analysis of Sensations itself by no means mandates the phenomenalist reading, and that a case for something more like the neutral monist reading can be made from within that book, indeed largely from within its famous first chapter.

Mach's Argument against Traditional Philosophical Views, and the Appearance/Reality Distinction

Mach situates his own view as preferable to traditional philosophical views, and his argument against those turns on the idea that certain familiar tendencies of thought, when pursued, lead to intolerable conclusions, in the form of pseudo-problems. Mach is clear that designating relatively permanent complexes of sensations using singular terms is a perfectly acceptable instance of 'the partly instinctive, partly voluntary and conscious economy of mental presentation and designation' (p. 3), and that it is useful (p. 6). But he thinks its usefulness extends only so far. When we have moved beyond what he calls a 'first survey' of our substance-concepts (p. 5), this initial habit comes into conflict with a second movement of thought, 'a more exact examination of the changes which take place in these relatively permanent existences' (p. 5), a movement that involves 'the tendency to isolate the component parts' (p. 6). When it comes to bodies, for example, a natural line of philosophical reasoning then tempts us into a certain misconception:

\footnotetext{
${ }^{3}$ Unless otherwise stated, all quotations are from (Mach 1886/1914). I have not hesitated to quote from the English translation, the whole of which was read by Mach (p. xxxiv), whose English was very good (Blackmore 1972, p. 9). But, wherever the wording is crucial, I have also given the original German. Throughout, page references to the German text (in the form 'S. $\mathrm{n}^{\prime}$ ) are to the relevant volumes of the recent Ernst Mach Studienausgabe. No doubt I ought also to apologise for concentrating, as so many have done, on the first chapter of The Analysis of Sensations. My excuse is simply that it is one of my favourite philosophical texts.
} 
The vague image which we have of a given permanent complex, being an image which does not perceptibly change when one or another of the component parts is taken away, seems to be something which exists in itself. Inasmuch as it is possible to take away singly every constituent part without destroying the capacity of the image to stand for the totality and to be recognised again, it is imagined that it is possible to subtract all the parts and to have something still remaining. Thus naturally arises the philosophical notion... of a 'thing-in-itself', different from its 'appearance', and unknowable (p. 6).

This idea is, for Mach, the end point of a reductio ad absurdum since, like so many thinkers in Kant's wake, he finds the idea of the thing-in-itself to be intellectually intolerable. Here he calls that idea 'monstrous' (ibid.).

Similarly, when it comes to the ego, a dilemma is posited for the supposition that the ego is a real unity, the first horn of which is that we would have to 'set over against the ego a world of unknowable entities (which would be quite idle and purposeless)' (p. 28). And much later in the book Mach distances himself from any conception of 'a transcendental, unknowable ego, which many philosophers perhaps still think it impossible to eliminate as a last remnant of the thing-in-itself' (p. 359, note).

These are among the 'series of troublesome pseudo-problems' ( $p . x l)$ that Mach takes his book to be intended to eradicate. He says explicitly that 'That protean pseudo-philosophical problem of the single thing with its many attributes, arises wholly from a misinterpretation of the fact, that summary comprehension and precise analysis, cannot be carried on simultaneously' ( $p$. 7), and that 'the ego itself... gives rise to similar pseudo-problems' (p. 8). He later explains that although an encounter with Kant's Prolegomena made an enormous impression upon him around the age of fifteen, two or three years later he came to see the superfluity of the 'thing-in-itself' ( $p .30$ note). Avoiding the suggestion of any such propertyless and unknowable entities is a Leitmotiv of his philosophy.

Mach's opposition to the appearance/reality distinction is also based on this same horror noumena. Discussing Plato's parable of the cave, which deploys that distinction to such great effect, Mach urges that it has not been thought out to its final consequences, 'with the result that it has had an unfortunate 
influence on our ideas about the universe. The universe, of which nevertheless we are a part, became completely separated from us and removed an infinite distance away' (pp. 11-12). I take this to be related to the idea that postulating an unknowable thing-in-itself will be inevitable.

Why Mach's View wasn't Phenomenalism

'Phenomenalism' has been the name for different views in the history of philosophy. When Mach's follower Hans Kleinpeter advocated it, for example, he had in mind a 'natural-scientific world view' incorporating various claims, some of which overlap with what I mean here by 'phenomenalism' (e.g., that sensations are the ground of our knowledge), others of which do not (e.g., the rejection of the mechanical world-view, and the idea that concepts are mere labels (see Gori 2012)). ${ }^{4}$ I shall be concerned with what I take to be the root of the term's principal modern meaning, according to which everything concrete, including physical objects, can be 'reduced to' 'sensations', where these latter are conceived of as purely psychological phenomena. (Thus, I do not mean to confine it to a thesis about language, but rather to capture both linguistic and non-linguistic phenomenalism - this is what most of those who read Mach as a phenomenalist (or a 'sensationalist') have had in mind).

There is one absolutely central feature of Mach's published views that doesn't fit phenomenalism, and this is the nature of his 'elements'. In The Analysis of Sensations this is stressed several times, first in the following passage which warns readers against a misunderstanding of the term 'sensation':

In what follows, wherever the reader finds the terms 'sensation', 'sensation-complex', used alongside of or instead of the expressions 'element', 'complex of elements', it must be borne in mind that it is only in the connection and relation in question, only in their functional dependence, that the elements are sensations. In another functional relation they are at the same time physical objects. We only use the additional term 'sensations' to describe the elements, because most people are much more familiar with the elements in question as

\footnotetext{
${ }^{4}$ Luca Guzzardi pointed out to me that Kleinpeter sometimes took 'phenomenalism' to be the view that the laws of nature are descriptions of phenomena (rather than attempts to specify real causes).
} 
sensations (colours, sounds, pressures, spaces, times, etc.), while according to the popular conception it is particles of mass that are considered as physical elements, to which the elements, in the sense here used, are attached as 'properties' or 'effects' (p. 23).

This is reiterated in a similarly insistent passage on p. 44, and then again in a passage within the 1902 'Preface to the Fourth Edition' (p. $x l) .{ }^{5}$ These passages should leave us in no doubt that Mach did not mean to be the usual kind of 'phenomenalist', that is the kind who, after identifying 'elements', would characterise them as psychological and not physical. (Obviously they also rule out, in the same way, his being a materialist).

There are still two ways of putting the resulting view, though. The first way, which to me more explicitly courts Russell's designation 'neutral monism', is to say that the nature of the basic reality is neither mental nor physical. Mach does sometimes speak this way, saying of forms and colours that they are 'in themselves neither psychical nor physical' [an sich weder psychisch noch physisch (S. 67)]. The second way of putting matters is to say that the basic reality is always both mental and physical. Mach seems to have preferred this latter way of putting things, as in the long quotation above. (The original reads 'Sie sind in anderer funktionale Beziehung zugleich physikalische Objekte' (S. 23)). Another passage giving the same impression, and where ' $A$ ' refers to the green of a leaf, runs:

Now in its dependence upon $B C D$ [sensations of space, touch, and sight]..., $A$ is a physical element, in its dependence on $X Y Z$ [the elements of a retinal process]... it is a sensation, and can also be considered as a psychical element. The green $(A)$, however, is not altered at all in itself, whether we direct our attention to the one or to the other form of dependence. I see, therefore, no opposition of physical and psychical, but simple identity as regards these elements. In the sensory sphere of my consciousness everything is at once physical and psychical [ist jedes Objekt zugleich physisch und psychisch (S. 48)] (p. 44).

\footnotetext{
${ }^{5}$ In Mach's later article 'Some Questions of Psycho-Physics' we are told that 'the same A B C... are both physical and psychical elements' (Mach 1891, p. 398).
} 
This, I think, might most naturally be called a 'dual-aspect' view. However, and when distancing himself from other views, Mach takes care to point out that his is not a conception like that of Gustav Theodor Fechner, which is what Mach himself understood by the phrase 'dual-aspect view'. ${ }^{6}$ Mach says:

The view here advocated is different from Fechner's conception of the physical and the psychical as two different aspects of one and the same reality. [...] We refuse to distinguish two aspects of an unknown tertium quid; the elements given in experience, whose connection we are investigating, are always the same, and are of only one nature, though they appear, according to the nature of the connexion, at one moment as physical and at another as psychical elements (p. 61).

However, whether we state Mach's view in terms of the basic reality being neither mental nor physical, or alternatively in terms of its being both mental and physical, the 'neutrality' of that reality is preserved: it is equally physical and mental.

A second kind of evidence for Mach's not being a phenomenalist is supplied by his several attempts to situate his own view, and his explicit attempts to distance himself from idealism. We now distinguish between idealism and phenomenalism, as Mach did not, but the reason he gives for not being an idealist would make an equally good case for not being a phenomenalist, in the sense specified above.

In the main text of The Analysis of Sensations, although Mach uses the term 'element' throughout the book's first chapter, in the place where he most explicitly justifies using this term in his proprietary sense he says 'Usually, these elements are called sensations. But as vestiges of a one-sided theory inhere in that term, we prefer to speak simply of elements' (p. 28). The 'one-sided theory' in question here is idealism. Mach admits that his mature view developed from an earlier idealism of his own. When defending himself from the accusation that his view is a Berkeleyan idealism he says

\footnotetext{
${ }^{6}$ See Heidelberger 2010, where it is explained that this was Fechner's pre-1855 view only.
} 
This misconception is no doubt partly due to the fact that my view was developed from an earlier idealistic phase, which has left on my language traces which are probably not even yet entirely obliterated. For, of all the approaches to my standpoint, the one by way of idealism seems to me the easiest and most natural (pp. 361-2).

He subsequently explains how a Kantian idealism had been the 'starting-point' of his critical thought, but that he soon gravitated 'towards the views of Berkeley', which he regarded as lying latent within Kant's writings (pp. 367-8). He then mentions that his views went on to develop towards those of Hume (who can also be thought of as an idealist, for sure).

None of this idealist intellectual ancestry, however, should make us characterise the view Mach eventually arrived at as idealism (whether phenomenalist or not). In the 1901 'Preface to the Third Edition' of the book, he took the trouble to point out that 'Some passages of the second edition have been cast in clearer form, since they were often understood in a one-sided idealistic sense, an interpretation which I in no wise intended' (p. xxxix). ${ }^{7}$ There should be no doubt that by speaking of idealism as 'one-sided' Mach had in mind the way idealism portrays the basic nature of reality as mental (rather than physical). Materialism, for him, was equally 'one-sided' (see Mach 1895/1896, p. 385). But this accusation of one-sidedness would apply equally as well to phenomenalism as to any other version of idealism, since phenomenalists, too, in trying to 'reduce' physical things to sensations, conceived of as purely mental, make the basic nature of reality mental. When Mach commented on the phenomenalism which would have been most familiar to him, John Stuart Mill's conception of objects as 'permanent possibilities of sensation', he expressly distanced himself from it (p. 363). ${ }^{8}$

Finally, if Banks is right, Mach's admittedly occasional (and largely unpublished) gestures towards the existence of 'world elements', that is, 'elements that are not interpretable as anyone's sensations' (Banks, this volume, p. ?0) would also point decisively away from phenomenalism. No-one who

\footnotetext{
${ }^{7}$ See also Mach 1905/1976, p. 114.

${ }^{8}$ Evidence against the phenomenalist reading from elsewhere includes Mach 1891, pp. 3978, Mach 1895/1896, pp. 208-9, and Mach 1910/1970, pp. 38-40.
} 
thinks the world is constructed out of 'elements' which have to be psychological could acknowledge elements which exist beyond (human, or any) mentality.

Why Mach's View has been Thought to be Phenomenalism

None of these declarations definitively refute the suggestion that Mach was a phenomenalist of some kind. They are all compatible with his view's being a version, a non-idealist version, of that view. So the more careful way to put my thesis is that if, but only if, phenomenalism interprets 'elements' as mental but not physical, then Mach would have rejected it. ${ }^{9}$ But I hope to show now that the main factors that tempt people into seeing Mach as a phenomenalist (or an idealist of any kind) are in no way decisive in that direction, that they can all be explained by a correct understanding of what he meant in each case. Those main factors in The Analysis of Sensations, as I see it, are:

1. The way in which he understands our existing 'substance-concepts' of bodies and egos as 'complexes of elements'

2. The way in which he ties 'sensations' (Empfindungen) to the subject

3. His characterisation of sensations and elements as 'given'

4. His actual examples of 'sensations' and 'elements'

5. The way in which his 'sensations' and 'elements' are supposed to depend on the physiology of the senses

6. His characterisation of spaces and times as 'sensations'

Let us look at each of these in turn.

Factor 1: Substance-Concepts as Referring to 'Complexes of Elements'

Mach speaks often of both bodies and egos being complexes of elements. For the former, we have his declarations that what get called bodies are 'complexes of colors, sounds, pressures, and so forth' (p. 2), that 'thing, body, matter, are nothing apart from the combination of the elements' (p. 6), that 'Bodies do not produce sensations, but complexes of elements (complexes of

\footnotetext{
${ }^{9}$ As long as the phenomenalist doesn't say that, but thinks of all 'phenomena' as equally mental and physical, commentators such as Blackmore and Agassi might be right to characterise Mach as a phenomenalist as well as a neutral monist (thinking of neutral monism as a kind of phenomenalism) (Blackmore ibid., p. 64, Agassi 1978/1988, p. 23)).
} 
sensations) make up bodies' (p. 29), and that 'all bodies are but thought-symbols for complexes of elements (complexes of sensations)' (ibid.).

When it comes to the latter, the provocative ideas are that each ego is a 'complex of memories, moods, and feelings, joined to a particular body' (p. 3), or that 'It is out of sensations that the subject is built up' (p. 26).

Further, both bodies and egos, Mach is keen to insist, are only of relative permanency (pp. 2-4), and in 'a more exact examination of the changes that take place in these relatively permanent existences' these complexes are seen to be 'made up of common elements', and can be 'disintegrated into elements' (p. 5).

There is no doubt that these pronouncements are high on the list of things that tempt commentators to compare Mach with Berkeley, for example. However, they should lead us to think of Mach as a phenomenalist or idealist of some kind only if he had not told us that 'elements' are always both mental and physical. As long as one bears this insistence in mind, there is nothing inherently idealist here.

Factor 2: 'Sensations' and the Subject

Mach talks sometimes of elements, and sometimes of sensations (Empfindungen). However, some of the things he says about sensations (but not about elements) seem to tie them to the subject, and this tie can easily be given an ontological reading. Here I am not referring to his merely using the word 'sensation'. We already saw that he warned his readers about the way he was using that word, and that he tried to accustom us to call them 'elements' instead (p. 23). If the phenomenalist reading relies on ignoring that warning, so much the worse for it. Sensations, for Mach, are not merely psychological, but always also physical.

Nevertheless, Mach quite often ties 'sensations' to the subject (or to plural subjects). So, for example, in a crucial place where he is presenting his own view, Mach says 'The assertion, then, is correct that the world consists only of our sensations. In which case we have knowledge only of sensations,....' [Es ist dann richtig, dass die Welt nur aus unseren Empfindungen besteht. Wir wissen aber dann eben nur von der Empfindungen] (p. 12 (S. 20)). ${ }^{10}$ The word 'our' is what

\footnotetext{
${ }^{10}$ Elsewhere, the phrase 'my sensations' occurs in 'Some Questions of Psychophysics' (p. 394), and 'our sensations' in Mach 1872/1911, p. 91, SM, p. 559, Mach 1895/1896, pp. 200, 209 ('the world is our sensation').
} 
should worry us here. Despite identifying his 'elements' with sensations, Mach doesn't use the phrase 'my elements', and only uses the phrase 'our elements' to mean 'the elements we have supposed' (e.g. Mach 1905/1976, p. 12, note 7). Why then can sensations be characterised as mine, yours, or ours? (Unless this merely means 'the sensations we have supposed', which seems very unlikely in the context). And why, if there exist 'world elements', doesn't the world instead consist of our sensations plus these others?

Although this is a good question, and this phrase might create a presumption against Banks's reading, it is not good evidence for any idealist reading. By calling them 'our' sensations Mach may just have been characterising their accessibility to us, not their ownership by us. The world consists in our sensations because those are the sensations we all have access to. What's important is that Mach never characterises elements as mine, yours, or ours. He can allow that 'sensations' can be owned, but that's because sensations are elements in their psychological connections. The laws of psychology (but not the laws of physics, of course) relate them to the ego (nonsubstantially conceived). I think that whenever Mach refers to 'our sensations' he can be understood in this way.

The import of his claim that 'the world consists of our sensations' is to deny the knowability (and thereby the meaningfulness of any assertion of the existence of) of things-in-themselves, not to deny the existence of physical phenomena. As we shall later see, Mach clearly states that 'sensations' are partly (or in certain respects) physical.

In the second place where this world constitution-thesis appears, there is no mention of our sensations. But something else problematic takes its place:

[P]erceptions, presentations, volitions, and emotions, in short the whole inner and outer world, are put together, in combinations of varying evanescence and permanence, out of a small number of homogeneous elements. Usually, these elements are called sensations. But as vestiges of a one-sided theory inhere in that term, we prefer to speak simply of elements (p. 22).

Here one problematic idea is that the outer world might comprise items from the list: perceptions, presentations, volitions, and emotions. Given that all those 
items would normally be thought of as psychological (and not physical), Mach's declaration that the 'whole inner and outer world' [die ganze innere und aüßere Welt (S. 28)] is comprised of them sounds idealist. (Unless by 'the outer world' he means merely our representation thereof, which is unlikely in the context). But the important thing here is that these items are in turn put together out of his 'elements', which he explicitly tells us are not exclusively psychological. Thus there is no reason here to suspect him of phenomenalism.

However, there is still a problem. How can perceptions, presentations, volitions, and emotions exhaust the contents of the (i.e. be the whole) outer world? It's difficult to see any way of taking this that isn't idealist, or which would not preclude the existence of genuine 'world elements' (understood as elements that are not interpretable as 'sensations'). Neutral monist readers might seem well-advised to regard this as one of the more careless things Mach says, an example of what Erwin Hiebert called Mach's 'philosophically unbuttoned' comments.

I suspect that the best construction that can be put upon this remark of Mach's is as follows. 'Elements' are related to one another in two ways. 'Sensations' are merely elements as seen in their psychological connection. The whole world consists of 'sensations', then, only in the sense that each element stands in some psychological relation to other elements. Elements exhaust the content of the world, and each element can be viewed not only in its physical connection to other elements, but also in its psychological connection to them.

This supports the neutral monist reading. Unfortunately, though, I think it must impact negatively either on Banks's characterisation of 'world elements' as 'elements that are not interpretable as anyone's sensations', or on the supposition that Mach postulated such elements, for it puts 'world elements' beyond mentality. It not only makes their physical connections more basic than their psychological connections; it means that not all elements are psychologically connected. This would wreck the neutrality of Mach's neutral monism, and perhaps it explains why almost all his remarks on world elements remained confined to his notebooks. ${ }^{11}$

Factor 3: Characterising Sensations and Elements as 'Given'

\footnotetext{
${ }^{11}$ In fact, when Mach himself used the term 'Weltelemente' in print (S. 37), he explicitly means the elements he has already introduced in the book.
} 
A third factor, linked with this second one, is surely Mach's quite frequent characterisation of sensations and/or elements as 'given'. There should be little doubt that Mach's empiricism involved some kind of foundationalism about 'sensations'. ${ }^{12}$ So, for example, he says that 'I have the sensation green, signifies that the element green occurs in a given complex of other elements (sensations, memories)' [in einem gewissen Komplex von anderen Elementen] (p. 23 (S. 30)), that 'elements form the real, immediate, and ultimate foundation [die eigentliche, nächste und letzte Grundlage], which it is the task of physiologicophysical research to investigate' (p. 29 (S. 34)), that 'colors, sounds, spaces, times,... are provisionally the ultimate elements, whose given connexion it is our business to investigate' [vorläufig die letzten Elemente, deren gegebenen Zusammenhang wir zu erforschen haben] (pp. 29-30 (S. 35)) and most explicitly, referring to those elements which compose what we normally think of as physical objects other than our own body, he calls them 'immediately and indubitably given' (p. 45) [unmittelbar und unzweifelhaft gegeben (S. 49)]. His empiricist preference for what is 'given' is also reflected negatively in certain dismissals of what is not 'given', for example in the idea that 'reference to unknown fundamental variables which are not given (things-in-themselves) is purely fictitious and superfluous' (p. 35) [die Beziehung auf unbekannte, nicht gegebene Urvariable (Dinge an sich) eine rein fiktive und müßige ist (S. 39)].

However, Mach's willingness to characterise sensations/elements as 'given' should not be taken to mean that for him they must be purely mental or psychological, which is what would be necessary to sustain any idealist reading. That they are 'given' to us is (again) only an epistemological relation, and is not supposed to include or support any ontological classification. That they are the sorts of things we experience does not mean, for Mach, that their nature is solely psychological. Later on, in his debate with Max Planck, Mach was absolutely explicit that 'There can be no question of interpreting sensations in a purely subjective way, as Planck seems to assume' (Mach 1910/1970, p. 40).

Factor 4: Mach's Examples of 'Sensations' and 'Elements

\footnotetext{
12 In his essay for this volume Banks denies this, and appeals to Feyerabend 1970/1999. But what's said there suggests (rightly or wrongly) only that Mach was not a 'radical' or classical foundationalist.
} 
As we saw, Mach does warn his readers that the terms 'sensation' and 'element' should not be used entirely interchangeably (p. 23). But the actual examples of 'sensations' and 'elements' which he gives often have a curious character. In the first chapter of The Analysis of Sensations, all of the following things are said to be 'elements':

A stain on a coat or a tear in its fabric (p. 3)

Colours, tastes, and hedonic qualities (usually thought of as properties) that are common to different complexes (complexes usually thought of as bodies) (p. 5)

Colours, sounds, and other features of bodies which are usually thought of as their attributes (pp. 6-7)

The constituents of 'those complexes of colors, sounds, and so forth, commonly called bodies' (p. 8)

The constituents of the complex commonly known as our own body (p. 9)

The constituents of the complex composed of volitions, memory-images, and the rest' (ibid).

A pencil, its being seen by us as straight, water, the pencil's being seen as crooked when half-immersed in the water, a bright surface, and how that surface appears (p. 10)

A prick from a pin, and the resulting pain (p. 13)

In the 'white ball' example (discussed below), sounds, colours, pressures, spaces, times, and maybe even the ball itself (p. 16)

Colours, sounds, spaces, times, motor sensations, etc. (p. 21)

Green (pp. 23, 43)

Sensations, memories (p. 23)

Colors, sounds, spaces, times (pp. 29-30)

The green of a leaf (p. 44)

When it comes to the term 'Empfindung', Mach uses that to cover individual physical bodies such as a table and a tree (p. 13 note), sounds, colours, pressures, spaces, times (p. 16), as well as the colour green, and the green of a specific leaf (pp. 23, 43). Having explained his concepts, Mach often uses the compound expression 'elements (sensations)' (pp. 23, 25, 26) in order to draw attention to the overlap. 
As well as this overlap, various things should be noted about these examples. Firstly, Mach's examples of elements and Empfindungen are entirely homely phenomena, and not obscure unfamiliar entities from the theoretical reaches of any science. No such entity figures as an example. So although Mach tells us that colours, spaces and times are only 'provisionally the ultimate elements' (p. 29, emphasis added), no future discovery of any more ultimate basis should be taken as withdrawing these examples.

Secondly, they are phenomena drawn just as much from what philosophers would think of as the category of the physical as from that of the mental.

Thirdly, they pointedly slew across the appearance/reality distinction which, as we saw, Mach scouted (p. 10). They include what we would normally think of as phenomena a person merely thinks they perceive, as well as phenomena they really do perceive. In this respect, his elements and sensations might be thought of simply as data..$^{13}$

What tempts people towards an idealist reading here is simply our tendency to think of many of these things as psychological but not physical. For philosophers, at least, volitions, memory-images, and motor sensations might seem to be paradigm examples of purely mental events, and an effort would often be made to squeeze colours and sounds into that same category.

The thing to remember here is that Mach also counts physical things, and spaces, and times, as complexes of elements. But this is not the end of the argument. The underlying worry is that when it comes to telling us what bodies, spaces, and times are, Mach can refer only to other 'elements', the ones that look more eminently and exclusively psychological. This may be so, but for Mach none of these elements are exclusively psychological. Even our paradigm examples of mental phenomena, no matter how 'inner' or 'phenomenal' they may be, Mach thought of as having both a psychological and a physical nature. That was the legacy of his deep immersion in psychophysics: always finding a physiological aspect to any psychological phenomenon. Because his interest was in functions, connections, any way in which a psychological phenomenon could be affected by altering something physical counts as a respect in which that

\footnotetext{
13 Cf. Richard von Mises' intriguing suggestion that 'All the elements, which Mach calls "sensations", could perhaps be called by a more neutral term such as is used in photography, "takes"' (von Mises 1938/1970, p. 261).
} 
phenomenon is physical. Seen thus, Mach might look to us more like a liberal and non-reductionist kind of 'physicalist', and might be ranked against more recent thinkers like Thomas Nagel, and David Chalmers, who postulate, or suppose they can discern, mental phenomena which have no physical aspect. His psychophysical project was the investigation of physical (physiological) and psychological aspects of the same events or qualities. The events or qualities in question are related to one another in the physical way by certain laws, and in an entirely different, psychological way, by a different set of laws. In one of the two available 'directions of investigation' he mentions (p. 18) they are investigated by physiology, and in the other by psychology (whose method he conceived of as introspective).

Factor 5: Dependence on the Physiology of the Senses

This brings us to another factor also falling under the heading of 'things Mach says about (what he calls) "sensations" or "elements": the way he supposes these to vary and to depend upon 'the physiology of the senses'. Consider his discussion of perceiving a cube:

A cube when seen close at hand, looks large; when seen at a distance, small; its appearance to the right eye differs from its appearance to the left; sometimes it appears double; with closed eyes it is invisible. The properties of one and the same body, therefore, appear modified by our own body; they appear conditioned by it (p. 9).

To conclude that properties of physical objects 'appear modified' by the conditions of the perceiver's body is suitably modest and unobjectionable. Contrast this, though, with a passage from only a few pages later:

A white ball falls upon a bell; a sound is heard. The ball turns yellow before a sodium lamp, red before a lithium lamp. Here the elements $(A B C .$. appear to be connected only with one another and to be independent of our body ( $K L M$...). But if we take santonin [a drug which turns yellow on exposure to light], the ball again turns yellow. If we press one eye to the side, we see two balls (p. 16). 
The general conclusion Mach is driving at here he later expresses thus:

[T] he elements which belong to the sensible world... stand in a relation of quite peculiar dependence to certain of the elements $K L M-$ the nerves of our body, namely - by which the facts of sense-physiology are expressed (pp. 35-6).

As long as by 'the ball' we mean the physical object in question, a white ball doesn't literally 'turn yellow' or red, depending on whether it is illuminated by a coloured light or whether one has just taken a drug. Only if by 'the ball' one is speaking loosely, and meaning something like the way the ball looks or appears is it correct to say that 'the ball' changes colour under such conditions. This consideration surely plays directly into the suspicion that Mach must be a phenomenalist since, for this argument for the dependence of 'elements' on environmental or physiological conditions to work, he must be identifying 'the ball' with its appearances.

Of course Mach might protest against such an invocation of the appearance/reality distinction (which, we saw, he criticises (pp. 10-12)). But he has to make his view intelligible to us in terms of the ways of thinking and speaking we all (by his own account) start from and, given the incorrectness of saying that the ball really does turn yellow, we are at a loss to find something that really turns yellow unless we make the familiar philosophical move of conjuring up something mental, e.g., a collection of appearances, sense-data, or whatnot. This, I conjecture, is one of the more powerful reasons people have had for taking him to be a kind of idealist.

Is there any way of defending Mach against the accusation of incipient phenomenalism here? Merely deploying his excuse that an earlier idealism left traces on his way of expressing himself (p. 362) does not look promising. It's not merely that his language implies the existence of mental phenomena such as appearances (in the way, e.g., sense-datum theorists do). His argument won't work unless he identifies the ball with such phenomena. And that puts him firmly in the phenomenalist camp.

If there is a way to resist categorizing Mach thus, it involves insisting again that to say that something depends upon facts about sensory physiology isn't yet to identify it as exclusively mental. For Mach, that the 'elements' seen alter 
in the transition between what we would ordinarily describe as these two situations:

- one in which we see a white ball

- one in which a sodium lamp is shone on that same white ball

is undeniable, for these elements are all (or almost all) we experience. But even to identify them as what is experienced is not yet to make them exclusively mental. For Mach, what we experience is as much physical as it is mental. When he tells us that certain matters depend on the physiology of the senses, this should not make us think of those matters as exclusively mental.

Factor 6: Spaces and Times as 'Sensations'

A final factor which makes people think of Mach as a phenomenalist or idealist is, I believe, of even greater importance. Early on in The Analysis of Sensations comes the striking declaration that 'The physiology of the senses... demonstrates that spaces and times may just as appropriately be called sensations [Empfindungen] as colours and sounds' (p. 8) ${ }^{14}$, and at this point Mach says that he will explain this idea later in the book. What subsequently happens in the chapters devoted to space (notably chs. VI, VII, and IX) and to time (ch. XII), though, supplies little that goes towards this end. Mach does argue that certain memory-phenomena can be more easily understood if we conceive of time as a sensation (p. 246), and that our idea of an invisible, immovable space must be based on and secondary to the space of motor-sensations (p. 139), but these considerations are surely not weighty enough to warrant the very substantial conclusion that spaces and times are sensations.

Mach's conception of sensation (or rather of what counts as an Empfindung) is, it has to be said, strange. He remarks that

Ordinarily pleasure and pain are regarded as different from sensations. Yet not only tactual sensations, but all other kinds of sensations, may pass gradually into pleasure and pain. Pleasure and pain also may be justly termed sensations (p. 21).

${ }^{14}$ See also Mach 1883/1960, p. 611. 
From the point of view of our everyday conceptual scheme and the English term 'sensation', this has matters backwards. Pangs of pleasure and pain are paradigms of sensations in the ordinary sense. Tactual sensations and temperature sensations are in the same position. But this does not mean that the other things Mach usually calls 'sensations' (colours and sounds) deserve that title, let alone that it can be applied to spaces and times. The English term 'sensation' is conceptually connected to that of feeling, sensations being what is felt in the relevant organ by the person concerned. Pleasure and pain are felt phenomena, there being no unfelt (or 'unowned') pleasures or pains. Touching things with the relevant sensitive parts of one's body, too, does typically issue in feelings, tactile sensations. Sounds can produce feelings, and thus sensations, if they are very loud or piercing, but normally they are heard, not felt, and thus involve no sensations. Colours, though, simply cannot be felt in vision, and (pace a host of empiricist philosophers) produce no sensations in the eye.

Did Mach, despite aiming to free himself (and science) from past philosophies, simply buy into the mainstream empiricist tradition in this respect? Perhaps not. I suspect that he used the term 'Empfindung' in a much broader way, to mean something like 'anything we can be said to sense' (or even 'anything we can be said to even think we sense', since he explicitly includes what we would think of as misleading ways things seem to be).

His claim that spaces and times are Empfindungen might also be illuminated by going outside The Analysis of Sensations, back to his book History and Root of the Principle of the Conservation of Energy, where he tells us that 'Space and time are not here conceived as independent entities, but as forms of the dependence of the phenomena on one another' (Mach 1872/1911, p. 95 note). His ambition to move away from the idea that space and time are independent entities (substances) is creditable, and puts some distance between him and any metaphysical view such as idealism. Mach consistently thought of space and time in relational rather than substantival terms. Since ways in which phenomena depend on one another (relations) are neither inherently mental nor inherently physical, no form of idealism is in the offing. Mach's negative suggestion therefore has merit, although there may be no direct connection between relationalism and his view that spaces and times are sensations. Further, if I am right about the way in which he uses the term 
Empfindung, his positive claim amounts merely to the idea that spatial and temporal relations are things we sense. This sounds right but of course, pace Mach, no sensory physiology is required to demonstrate it.

The Physical and the Mental

None of these six factors means that the sensations/elements Mach has in mind are exclusively or even dominantly mental, though (by his lights). Unfortunately, they do look as if they must be mental when considered by the lights of certain philosophers, those who would classify perceptions, volitions, emotions, etc., as purely mental. Mach is committed to rejecting this, and to rejecting certain familiar associations which attach to our terms. He speaks of a 'great gulf between physical and psychological research [which] persists only when we acquiesce in our habitual stereotyped conceptions' (p. 17)).

So far, the single move of denying that 'elements' are solely psychological has served to rebut all the suggestions that Mach must be a phenomenalist. For Mach, all 'elements' are physical in certain connections, and mental in others. However, this throws all the weight on to his account of these terms, of what we mean when talking of phenomena being either physical or mental.

In virtue of what are 'elements' mental and physical, then? The answer lies in Mach's notion of 'connection' or, more strictly, functional dependence. Unfortunately, he puts this answer in different ways, not all of them satisfactory. Some imply mysteriously that dependence upon something physical (viz., the retina) could make an element psychological, and at the same time make it sound as though the same set of elements are physical (but not psychological) when 'considered as' connected with one another in one way, and psychological (but not physical) when 'considered as' connected with one another in another way (e.g., p. 17). Since 'considering something as so-and-so' is a psychological notion, the idea of aspects of reality either being or even appearing mental or physical because of how they are 'considered' (by humans) slants the ground in favour of idealism. The lesson is that Mach's story about what makes 'elements' mental and physical had better not rely on anything which is drawn from either of those categories. If it violates this condition by appealing to something psychological, it will inevitably give ammunition to those who think of him as some kind of idealist. 
Other formulations, such as when we're told that 'not the subject-matter, but the direction of our investigation, is different in the two domains' (pp. 1718), court a similar objection. What makes phenomena physical or mental shouldn't depend on matters as contingent and variable as the way in which we are currently investigating.

Happily, though, Mach has a better way of putting matters. What I take to be his official view is best put in one of the passages we saw already, where he says that it is only in the connection and relation in question, only in their functional dependence, that the elements are sensations. In another functional relation they are at the same time physical objects' (p. 16). This is the way of putting things that gets reiterated in this passage:

The fundamental constituents of (outer) bodies and human mental phenomena are the same (colours, sounds, spaces, times, motor sensations, etc.); only their character of their connection is different ( $p$. 21),

and in the important Preface to the Fourth Edition, where 'sensations' are said to be 'the common elements of all possible physical and psychical experiences, which merely consist in the different kinds of ways in which these elements are combined, or in their dependence on one another' ( $p . x \mathrm{l})$.

The relations adverted to here, of 'connection', and functional dependence are objective relations, but not physical or mental relations, so the objections above will not apply to them. Nevertheless there is something suspiciously solipsistic about a certain 'picture' which Mach thinks results from the basic neutral monist idea:

In this way,... we do not find the gap between bodies and sensations above described, between what is without and what is within, between the material world and the spiritual world. All elements $A B C \ldots, K L M \ldots$, constitute a single coherent mass only, in which, when any one element is disturbed, all is put in motion; except that a disturbance in $K L M$..., has a more extensive and profound action than one in $A B C$... A magnet in our neighbourhood disturbs the particles of iron near it; a falling boulder shakes the earth; but the severing of a nerve sets in motion the whole 
system of elements. Quite involuntarily does this relation of things suggest the picture of a viscous mass, at certain places (as in the ego) more firmly coherent than in others (p. 17).

The problem here is that it is only true that 'the severing of a nerve sets in motion the whole system of elements' if this 'system' is that of a single given person, since my having a nerve severed won't typically affect any elements accessible to you, unless we're nearby and I simply can't keep it to myself. Officially, Mach had little time for solipsism, but this proposed 'picture' does seem to court it, as does a closely related picture which came to him as the result of a sort of conversion-experience in his later youth: 'On a bright summer day in the open air, the world with my ego suddenly appeared to me as one coherent mass of sensations, only more strongly coherent in the ego' (p. 30, note 1).

\section{Mach as a Radically Revisionist Metaphysician?}

Mach, notoriously, did not consider himself a philosopher (p. 30 note, plus p. 368), or as putting forward any philosophical system (p. $\mathrm{xl}) \cdot{ }^{15} \mathrm{He}$ did publish in philosophy journals, though, and he eventually accepted the designation 'philosopher-scientist' [philosophierende Naturwissenschaftler] (Hentschel 1985, p. 391).

He would certainly have disavowed the title of metaphysician. His scorn for what he thought of as metaphysics appears absolutely undiminished through his career (pp. xxxviii, xl, 27 note, 30 note, 35,369 ). ${ }^{16}$ And yet, when we look at the things that tempt people into thinking he was a neutral monist, it is as a metaphysician that Mach now most naturally appears. In fact, in terms of Peter Strawson's famous dichotomy, he might seem to be the most radically revisionary of metaphysicians, intent on sweeping away the conceptual scheme common to our ordinary activities and science and replacing it entirely with a new science-inspired scheme, his scheme of elements. Of course, Mach might appear thus (and did not appear so to himself) because our idea of metaphysics

\footnotetext{
${ }^{15}$ Elsewhere, in the original Preface to Knowledge and Error, Mach again protests that he is not a philosopher (Mach 1905/1976, p. xxxi), and explains that he aimed not at introducing a new philosophy into science, but at removing an old one from it ( $p . x x x i i)$, although he does express the hope that philosophers might one day recognise his endeavour as a philosophical clarification of scientific methodology (p. xxxiii).

${ }^{16}$ See also Mach 1872/1911, pp. 9, 17, and Mach 1896/1986, pp. 1, 3.
} 
has changed. For us the notion has changed by being broadened through the idea of naturalistic metaphysics (and the associated naturalistic rejection of any 'first philosophy'). Could we bring him back today, Mach might well have come to see that he was a metaphysician, a metaphysician of this new, naturalist kind.

What, after all, did Mach understand by 'metaphysics' and the 'metaphysical'? When he used these terms he usually did so in what he took to be Kant's sense, meaning that which transcends experience (pp. $x l, 359$ note), and he associated this with the activities of scholastics, rationalist philosophers, and Kantians, all of whom postulated ontologies that were thus 'metaphysical'. This does not rule out thinking of Mach as also presenting an ontology, it means only that his ontology was not a metaphysical one.

We might therefore think of Mach as (a) associating metaphysics with philosophy (but not with science), (b) rejecting the notion that science (as an empirical discipline) could really answer metaphysical questions (since those questions are themselves suspect), (c) rejecting any philosophical (i.e., a priori) attempt to say what the fundamental nature of reality is, or what the fundamental components of reality are, and finally as (d) insisting that his own scheme of 'elements' was an attempt from within scientific research (p. 31) to supply science (but not necessarily anything outside of science) with a temporary platform across which the various sciences he was concerned with could best communicate. An ontology therefore, but not a metaphysical one. And an ontology postulated in the spirit that Mach saw science as having, that is, tentatively, and as subject to further analysis.

It is true that when Mach says 'The assertion, then, is correct that the world consists only of our sensations' (p. 12) this looks like the conclusion of an a priori argument from the untenability of the usual way of thinking, not a consideration deriving from the need for a platform across which sciences can communicate. However, the latter is the way in which Mach presents matters when he is at his best, as I see it. The Analysis of Sensations begins with him bemoaning the current state of science because of the 'unwonted prominence' of ways of thinking derived from physics, and an associated and inappropriate loss of way on the part of sensory physiology (p. 1). Mach's anti-reductionism (and the way he understood his own idea of the 'unity of science') then becomes evident in his reminder that physics 'constitutes but a portion of a larger collective body of knowledge' (p. 1), that it cannot exhaust the subject matter 
of science, and in his suggestion that the physiology of the senses could 'afford physical science itself powerful assistance' (p. 2). Later in the same first chapter it is most explicit in a wonderful passage in which Mach advertises his scheme of elements:

If we regard sensations, in the sense above defined, as the elements of the world, the problems referred to appear to be disposed of in all essentials, and the first and most important adaptation to be consequently effected. This fundamental view (without any pretension to being a philosophy for all eternity) can at present be adhered to in all fields of experience; it is consequently the one that accommodates itself with the least expenditure of energy, that is, more economically than any other, to the present temporary collective state of knowledge. Furthermore, in the consciousness of its purely economical function, this fundamental view is eminently tolerant. It does not obtrude itself into fields in which the current conceptions are still adequate. It is also ever ready, upon subsequent extensions of the field of experience, to give way before a better conception (p. 32, emphasis added).

That this is how Mach understood his proposed scheme is also evident from a similar passage in his Preface to the Fourth Edition of this same book. This passage makes it clear that he was not in the business of giving metaphysical questions naturalistic answers, but of disposing of such questions, since he regarded them as, or as posing, 'troublesome pseudo-problems' (p. xl). 'The aim of this book', he assures us

is not to put forward any system of philosophy, or any comprehensive theory of the universe.... [Rather,] [a]n attempt is made, not to solve all problems, but to reach an epistemological position which shall prepare the way for the co-operation of special departments of research, that are widely removed from one another, in the solution of important problems of detail (pp. xl-xli).

Mach's scheme of elements is both a (naturalistic) ontology, an attempt to say what exists, and a pragmatic program or proposal for linking sciences with one 
another. Whether that scheme really has all the virtues he advertised it as having I cannot say. But it does not fit with our contemporary philosophical naturalism, which usually endorses with so much glee the imperialism of physics (especially mechanics) that Mach was most concerned to resist.

Conclusion, and a Doubt about whether Mach was a Neutral Monist

On balance, I think the evidence from The Analysis of Sensations, at least, favours Mach's being more like a 'neutral monist' than a phenomenalist. The things that make him sound like a phenomenalist are incompatible with his basic viewpoint, as well as with his objecting to idealism as 'one-sided'.

Towards the end of the first chapter of The Analysis of Sensations, though, Mach sounds rather a different note, insisting that 'nothing would be changed in the actual facts or in the functional relations, whether we regard all the data as contents of consciousness, or as partially so, or as completely physical' (p. 36). This should come as a shock both to phenomenalist and to neutral monist readers. Phenomenalists can make no sense of it unless they drop the idea that elements (sensations) are purely psychological. But neutral monists must have trouble with it, too, for it implies that the categories of mental and physical don't really matter, and that the mental/physical 'distinction' is of no permanent applicability or integrity. The same note is sounded in a chapter from the second edition, when Mach endorses Rudolf Wlassak's account of Avenarius' proposal to abolish the terms 'physical' and 'psychical', Wlassak then crediting both thinkers with the idea of 'the untenability of the old conception of the psychical' (p. 51). What was crucial for Mach is that his 'elements' and their connections can be investigated both by physical sciences and by psychology. In The Analysis of Sensations, his concern was to draw science away from philosophies that generate pseudo-problems, and to ensure that the physical and the psychological sciences can communicate, interact, and benefit from one another. His real monism, the 'monistic point of view' (p. 14) [monistische Standpunkt (SS. 21-2)] is his unity of science thesis.

\section{References}

Agassi, Joseph (1978/1988) "Mach on the Logic of Enquiry: Taste-Maker Philosopher of Science", as reprinted in his The Gentle Art of Philosophical 
Polemics: Selected Reviews and Comments, (La Salle, IL: Open Court), pp. 21-32.

Banks, Erik C. (2003) Ernst Mach's World Elements: A Study in Natural Philosophy. Dordrecht: Kluwer Academic Publishers.

Banks, Erik C. (2014) The Realistic Empiricism of Mach, James, and Russell:

Neutral Monism Reconceived. Cambridge University Press.

Blackmore, John T. (1972) Ernst Mach: His Work, Life, and Influence. Berkeley:

University of California Press.

Blackmore, John T., R.Itagaki \& S.Tanaka (eds.) (2001) Ernst Mach's Vienna 1895-

1930 or, Phenomenalism as Philosophy of Science. Dordrecht: Kluwer.

Cohen, Robert S. (1968/1970) "Ernst Mach: Physics, Perception and the Philosophy of Science", Synthese, 18, as reprinted in Cohen \& Seeger 1970, pp. 126-164.

Cohen, Robert S. \& R.J.Seeger (eds.) (1970) Ernst Mach: Physicist and Philosopher. Dordrecht: Reidel.

Feyerabend, Paul K. (1970/1999) "Philosophy of Science: A Subject with a Great Past", as reprinted in his Knowledge, Science and Relativism: Philosophical Papers, Volume 3, ed. J. M. Preston (Cambridge University Press, 1999), pp. 127-137.

Feyerabend, Paul K. (1984) "Mach's Theory of Research and its Relation to Einstein", Studies in History and Philosophy of Science, 15, pp. 1-22.

Gori, Pietro (2012) "Nietzsche as Phenomenalist?", in H.Heit, G.Abel \& M.Brusotti (eds.), Nietzsches Wissenschaftsphilosophie: Hintergründe, Wirkungen und Aktualität, (Berlin: de Gruyter), pp. 345-355.

Hentschel, Klaus (1985) “On Feyerabend's Version of 'Mach's Theory of Research and its Relation to Einstein'", Studies in History and Philosophy of Science, vol.16, pp. 387-94.

Heidelberger, Michael (2010) 'Functional Relations and Causality in Fechner and Mach', Philosophical Psychology, 23, pp. 163-172.

Mach, Ernst (1872/1911) History and Root of the Principle of the Conservation of Energy. Chicago: Open Court.

Mach, Ernst (1883/1960) The Science of Mechanics. LaSalle, IL: Open Court. Mach, Ernst (1886/1914) Beiträge zur Analyse der Empfindungen, (Jena: Gustav Fischer, 1886. Further German editions in 1900, 1902, 1903, 1906, 1911, 1918, 1922). Translated by C.M.Williams \& S. Waterlow as The Analysis of 
Sensations and the Relation of the Physical to the Psychical, (Chicago \& London: The Open Court Publishing Company, 1914, reprinted New York: Dover Publications, 1959).

Mach, Ernst (1891) "Some Questions of Psycho-Physics: Sensations and the Elements of Reality", The Monist, 1, pp. 393-400.

Mach, Ernst (1895/1896) Populär-wissenschaftliche Vorlesungen, (Leipzig, 1896. Further German editions, 1897, 1903, 1910, 1923). Translated as Popular Scientific Lectures, trans. T.J.McCormack (Chicago: Open Court, 1895).

Mach, Ernst (1896/1986) Die Principien der Wärmelehre, historisch-kritisch entwickelt, (Leipzig: Johann Ambrosius Barth, 1896. Further German editions, 1900, 1919). Translated as Principles of the Theory of Heat, Historically and Critically Elucidated, ed. B.F.McGuinness. Dordrecht: D.Reidel.

Mach, Ernst (1905/1976) Erkenntnis und Irrtum. Skizzen zur Psychologie der Forschung, (Leipzig: Johann Ambrosius Barth, 1905. Further German editions, 1906, 1917, 1920, 1926). Translated by T.J.McCormack \& P.Foulkes as Knowledge and Error: Sketches on the Psychology of Enquiry, (Dordrecht: D.Reidel, 1976).

Mach, Ernst (1910/1970) "The Guiding Principles of My Scientific Theory of Knowledge and Its Reception by My Contemporaries", translated in S.E.Toulmin (ed.), Physical Reality: Philosophical Essays on TwentiethCentury Physics, (New York: Harper Torchbooks, 1970), pp. 28-43.

Russell, Bertrand (1914/1956) "On the Nature of Acquaintance, II: Neutral Monism", The Monist, vol.24, pp. 161-187, as reprinted in his Logic and Knowledge: Essays 1901-1950, ed. R. C. Marsh (London: George Allen \& Unwin, 1956), pp. 139-159.

Von Mises, Richard (1938/1970) Ernst Mach und die empiristische Wissenschaftsauffassung, (The Hague, 1938). (Translated as 'Ernst Mach and the Empiricist Conception of Science' in Cohen \& Seeger 1970, pp.245-270). 